\title{
Karakteristik dan Kebijakan Dividen Perusahaan Manufaktur yang Terdaftar di Bursa Efek Indonesia
}

\author{
Soliyah Wulandari \\ UIN Sultan Maulana Hasanuddin Banten \\ soliyah.wulandari@uinbanten.ac.id
}

\begin{abstract}
The aim of this research is to prove empirically the influence of firm characteristics. There are market price to book value ratio, firm age, market capitalization, debt equity ratio, earnings per share, liquidity, and growth of asset as firm characteristics. The research object are manufacture firm in Indonesian Stock Exchange during 2013-2017. The sample selection is using purposive sampling method. Based on criteria, samples which are used in this research are 37 firms. Secondary data are collected with documentation of financial statement from Indonesia Stock Exchange. Those data are processed using statistical test of multiple regressions. The result of this research proves that market price to book value ratio, debt equity ratio, earnings per share, and growth influence to dividend policy. In the other hand, firm age, market capitalization, and liquidity influence to dividend policy.
\end{abstract}

Keywords: Dividend policy, market price to book value ratio, firm age, market capitalization, debtequity ratio

\begin{abstract}
Abstrak
Penelitian ini bertujuan untuk membuktikan secara empiris pengaruh karakteristik perusahaan terhadap kebijakan dividen. Karakteristik perusahaan yang dimaksud adalah market price to book value ratio, umur perusahaan, market capitalization, debt equity ratio, earnings per share, likuiditas, dan tingkat pertumbuhan aset. Objek penelitian ini adalah perusahaan manufaktur yang terdaftar di Bursa Efek Indonesia pada tahun 2013-2017. Pemilihan sampel dilakukan dengan menggunakan metode purposive sampling. Berdasarkan pada kriteria, sampel yang digunakan dalam penelitian ini adalah 37 perusahaan. Data sekunder yang dikumpulkan adalah laporan keuangan dari Bursa Efek Indonesia. Data tersebut diolah menggunakan uji statistik model regresi berganda. Hasil penelitian ini membuktikan bahwa market price to book value ratio, debt equity ratio, earnings per share, dan pertumbuhan aset berpengaruh terhadap kebijakan dividen. Sedangkan, umur perusahaan, market capitalization, dan likuiditas tidak berpengaruh terhadap kebijakan dividen.
\end{abstract}

Kata Kunci: Kebijakan dividen, market price to book value ratio, umur perusahaan, market capitalization, debt equity ratio 


\section{PENDAHULUAN}

Kebijakan dividen merupakan suatu keputusan perusahaan untuk menentukan apakah laba yang diterima digunakan untuk pembagian dividen atau investasi dimasa mendatang. Hal ini akan berdampak terhadap reaksi dan sikap investor. Investor akan menilai negatif jika perusahaan tidak membagikan dividen atau memotong dividen. Perusahaan juga harus mempertimbangkan pertumbuhan perusahaan dengan memperhatikan investasi dimasa yang akan datang. Pembagian dividen juga memiliki pengaruh besar terhadap kreditur. Kreditur akan memberikan penilaian positif jika perusahaan membayar dividen kepada investor. Kreditur akan berpikir jika perusahaan memiliki kas yang cukup untuk pembayaran dividen sehingga perusahaan dapat membayar pokok dan bunga pinjaman.

Penting bagi investor maupun kreditor untuk dapat mengetahui faktor-faktor yang mempengaruhi perusahaan untuk memberikan keputusan pembayaran dividen kepada investor. Salah satu penentu kebijakan dividen yaitu karakteristik perusahaan (rasio keuangan dan umur perusahaan). Penelitian ini merupakan pengembangan dari penelitian sebelumnya yaitu Singhania \& Gupta (2012) mengenai faktor-faktor yang mempengaruhi kebijakan dividen. Namun terdapat beberapa perbedaan penelitian ini dengan penelitian Singhania dan Gupta.

Penelitian ini menambahankan dua variabel independen yaitu likuiditas dan pertumbuhan aset (Kuzucu, 2015). Penelitian Singhania \& Gupta (2012) menggunakan perusahaan yang terdaftar di Nifty Stock Exchange (India), sedangkan dalam penelitian ini menggunakan sampel perusahaan yang terdaftar di Bursa Efek Indonesia. Singhania \& Gupta (2012) menggunakan periode tahun 2000 sampai dengan 2010 sedangkan pada penelitian ini periode penelitiannya adalah tahun 2014 sampai dengan 2016.

Singhania dan Gupta menyatakan bahwa Market Price to Book Value Ratio adalah rasio antara harga pasar yang berlaku di pasar modal dan nilai buku perusahaan, untuk mengambil unit jumlah data perusahaan menurut pecking urutan perusahaan dengan pertumbuhan dan kegiatan investasi yang lebih baik memiliki kesempatan untuk mempertahankan lebih banyak dana untuk pendanaan internal dan sesuai membayar dividen lebih sedikit (Singhania \& Gupta, 2012).

Singhania dan Gupta (2012) menyatakan bahwa keberadaan suatu perusahaan diukur dari tahun berdiri perusahaan tersebut, untuk mengambil unit jumlah data perusahaan menurut pecking, perusahaan yang matang akan memberikan jaminan yang menjanjikan kepada investor karena perusahaan tersebut telah berdiri cukup lama dari awal perusahaan tersebut didirikan sampai saat ini, sehingga investor dapat tertarik untuk menginvestasikan dananya kepada perusahaan yang telah berusia cukup lama (Singhania \& Gupta, 2012). Penelitian Singhania \& Gupta (2012), Ressy dan Chariri (2013), dan Takhtaei (2014) menyimpulkan bahwa terdapat pengaruh umur perusahaan terhadap kebijakan dividen.

Singhania dan Gupta (2012) menyatakan bahwa total kapitalisasi pasar perusahaan sama dengan produk dari total saham harga yang luar biasa dan pasar unit saham 
perusahaan. Perusahaan dengan ukuran yang lebih besar dan proses yang lebih baik ke dalam pasar modal jarang mengandalkan informasi dari sumber internal dan dengan cara ini, akan cenderung untuk mendistribusikan dividen lebih, karena itu kapitalisasi pasar adalah penentu kebijakan dividen (Singhania \& Gupta, 2012). Penelitian yang dilakukan Singhania \& Gupta (2012), Devi \& Erawati (2014) serta Damayanti \& Martiningtiyas (2014) menyatakan bahwa terdapat pengaruh antara market to book value ratio terhadap kebijakan dividen.

Penelitian yang dilakukan Pasaribu, Kowanda, \& Nawawi (2014) serta Singhania \& Gupta (2012) berpendapat bahwa debt equity ratio terdapat pengaruh terhadap kebijakan dividen. Semakin rendah DER akan semakin tinggi kemampuan perusahaan untuk membayar seluruh kewajibannya. Hal ini disebabkan karena semakin besar proporsi hutang yang digunakan untuk struktur modal suatu perusahaan, maka akan semakin besar pula jumlah kewajibannya. Bukti empiris mengenai pengaruh earnings per share terhadap kebijakan dividen ditunjukan pada penelitian yang dilakukan oleh Damayanti \& Martiningtiyas (2014), dan Zameer et al. (2013) kenaikan earnings per share pada suatu perusahaan akan meningkatkan pembayaran dividen. Earnings per share yang semakin tinggi memungkinkan perusahaan untuk meningkatkan kapasitasnya dalam membagikan dividen. Hasil ini mengindikasikan bahwa semakin tinggi nilai earnings per share maka akan semakin tinggi pula kebijakan dividen perusahaan tersebut.

Tariq (2015) menyatakan bahwa likuiditas memiliki pengaruh terhadap kebijakan dividen dimana sejalan dengan penelitian Sunarya (2013). Namun dalam penelitian Darminto (2008) menyatakan likuiditas tidak memiliki pengaruh terhadap kebijakan dividen, dimana hal ini sejalan dengan penelitian yang dilakukan oleh Maladjian \& Khoury (2014). Adanya pengaruh negatif likuiditas terhadap kebijakan dividen menandakan bahwa semakin besar tingkat likuiditas perusahaan, maka dividen yang dibagikan oleh perusahaan akan menurun. Namun hal berbeda diungkapkan dalam penelitian Darminto (2008) serta Maladjian \& Khoury (2014) yang menyatakan bahwa besar atau kecilnya tingkat likuiditas perusahaan tidak akan mempengaruhi tingkat pembayaran dividen yang akan dibayarkan oleh perusahaan.

Thanatawee (2011) melakukan penelitian dengan hasil yang menunjukkan bahawa tingkat pertumbuhan aset berpengaruh terhadap kebijakan dividen perusahaan. Hal ini menunjukkan bahwa perusahaan dengan tingkat pertumbuhan aset yang tinggi akan memerlukan lebih banyak pembiayaan sehingga cenderung mengurangi pembayaran dividen kepada pemegang saham. Penelitian yang dilakukan oleh Marietta \& Sampurno (2013) Return On Assets, size increased but it is not followed by increase Dividend Payout Ratio. This research aims to analyze the effect mechanism of liquidity, profitability, growth, firm size and financial leverage against the dividend payout ratio at manufacturing companies listed on the Indonesia stock exchange (IDX menyatakan bahwa tingkat pertumbuhan aset tidak berpengaruh terhadap kebijakan dividen. Pernyataan tersebut juga setujui oleh Ritha \& Koestiyanto (2013). Hal ini mengartikan bahwa tingkat pertumbuhan perusahaan yang besar membuat perusahaan melakukan investasi dalam perusahaan lebih besar dibandingkan dengan membayar dividen kepada pemegang saham. 
Perbedaan tersebut diharapkan dapat memberikan kontribusi dan signifikansi penelitian ini. Tujuan penelitian ini adalah ingin membuktikan secara empiris pengaruh market price to book value ratio, umur perusahaan, market capitalization, earnings per share, likuiditas, dan tingkat pertumbuhan aset terhadap kebiajakan dividen. Oleh karena itu, penelitian ini mengangkat judul "Karakteristik dan Kebijakan Dividen Perusahaan Manufaktur yang Terdaftar di Bursa Efek Indonesia”.

\section{METODE}

Periode penelitian ini yaitu tahun 2014 sampai dengan tahun 2016. Metode pemilihan sampel yang digunakan adalah metode purposive sampling. Definisi operasional dan pengukuran untuk setiap variabel diuraikan sebagai berikut:

a. Kebijakan Dividen

Kebiajakan dividen merupakan keputusan perusahaan mengenai pembayaran dividen kepada para pemegang saham, apakah akan membayarkannya atau tidak, ketika memutuskan untuk membayarkannya berapa besarannya. Dalam penelitian ini, variabel kebijakan dividen menggunakan Dividend Payout Ratio (DPR) yang dirumuskan sebagai berikut:

$$
\text { DPR }=\frac{\text { Dividen Tunai }}{\text { Laba Bersih }}
$$

b. Market Price to Book Value Ratio

Market price to book value ratio adalah harga pasar yang berlaku di pasar modal dan nilai buku persahaan, untuk mengambil jumlah unit data perusahaan (Singhania \& Gupta, 2012). Dalam penelitian ini, variabel market price to book value ratio (MPBV) dirumuskan sebagai berikut:

$$
M P B V=\frac{\text { Harga Pasar Saham }}{\text { Nilai Buku Perusahaan }}
$$

c. Umur Perusahaan

Umur perusahaan (AGE) adalah keberadaan suatu perusahaan diukur dari tahun berdirinya perusahaan tersebut. Dalam penelitian ini, variabel umur perusahaan dirumuskan sebagai berikut:

$$
\mathrm{AGE}=\text { Years that company has been into existence }
$$

\section{d. Market Capitalization}

Market capitalization (MARCAP) adalah total kapitalisasi pasar perusahaan sama dengan produk dari total saham harga yang beredar dan harga pasar saham perusahaan (Singhania \& Gupta, 2012). Dalam penelitian ini, variabel market capitalization dirumuskan sebagai berikut:

$$
\text { MARCAP }=\frac{\text { Harga saham } \mathrm{x} \text { jumlah saham beredar }}{10.000 .000 .000}
$$


e. Debt-Equity Ratio

Debt-Equity Ratio (DER) adalah perbandingan antara total utang (termasuk jangka pendek dan utang jangka panjang) dan jumlah ekuitas (termasuk ekuitas dan cadangan dan surplus) perusahaan (Singhania \& Gupta, 2012). Dalam penelitian ini, variabel Debt-equity ratio dirumuskan sebagai berikut:

$$
\text { DER }=\frac{\text { Total Utang }}{\text { Total Ekuitas }}
$$

f. Earnings per Share

Earnings per share (EPS) adalah rasio total pendapatan dan jumlah saham yang beredar. Dikatakan semakin menguntungkan suatu perusahaan jika perusahaan tersebut mendapatkan laba yang melebihi target yang dicapai (Singhania \& Gupta, 2012). Variabel earnings per share dirumuskan sebagai berikut:

$$
\text { EPS }=\frac{\text { Total Pendapatan }}{\text { Weighted Average Saham yang Beredar }}
$$

g. Likuiditas

Pada penelitian ini likuiditas diukur menggunakan CR (Current Ratio). CR adalah rasio yang digunakan untuk mengukur dan evaluasi kemampuan membayar utang jangka pendek perusahaan menggunakan aset lancar (Kieso, Weygandt, \& warfield, 2017). CR diukur dengan rumus:

$$
\mathrm{CR}=\frac{\text { Aset lancar }}{\text { Utang lancar }}
$$

h. Tingkat Pertumbuhan Aset

Tingkat pertumbuhan aset (GROWTH) dari perusahaan mengidentifikasikan bahwa perusahaan cenderung menggunakan kas yang diperoleh dalam tahun berjalan untuk melakukan investasi kembali atau tidak. Menurut Alphonse \& Tran (2014) ukuran perusahaan dapat dihitung dengan:

$$
\text { GROWTH }=\frac{\left(\text { Total Aset }_{t}-\text { Total Aset }_{\mathrm{t}-1}\right)}{\text { Total Aset }_{\mathrm{t}-1}}
$$

Pengujian hipotesis digunakan untuk mengetahui pengaruh dari variabel independen terhadap variabel dependen yaitu rasio pembayaran dividen. Penelitian ini menggunakan model regresi berganda dengan persamaan sebagai berikut:

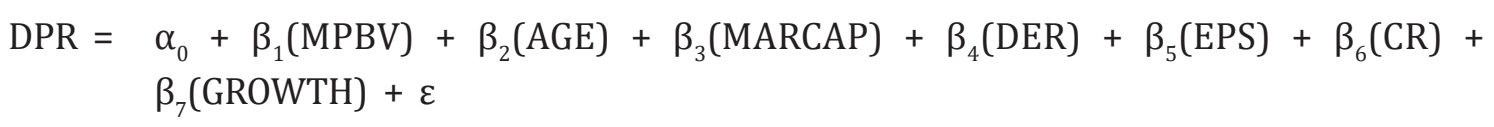

Keterangan:

DPR : Kebijakan dividen

$\alpha_{0} \quad$ : Konstanta

$\beta_{1} \ldots \beta_{7} \quad$ : Koefisien regresi 


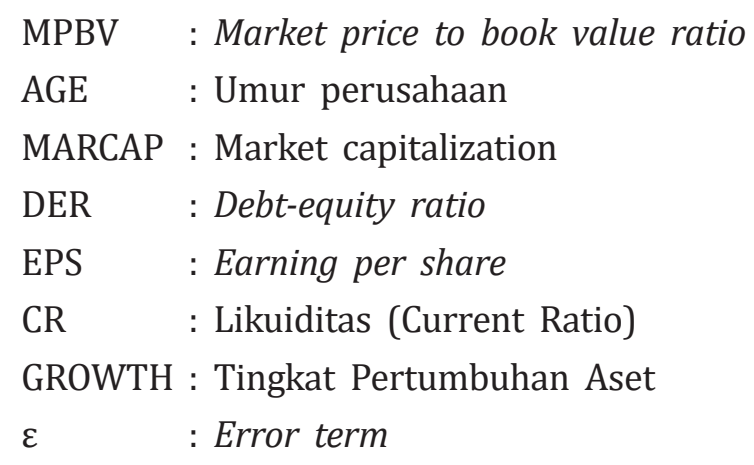

\section{HASIL DAN PEMBAHASAN}

Objek penelitian yang digunakan dalam penelitian ini adalah perusahaan manufaktur yang terdaftar di Bursa Efek Indonesia secara berturut-turut selama periode penelitian 2013-2017. Sampel yang digunakan dalam penelitian ini sebanyak 37 (tiga puluh tujuh) perusahaan yang dipilih sesuai dengan kriteria yang di uraikan pada tabel berikut:

Tabel 1. Prosedur Pemilihan Sampel

\begin{tabular}{lcc}
\hline \multicolumn{1}{c}{ Kriteria Sampel } & Jumlah Perusahaan & Jumlah Data \\
\hline $\begin{array}{l}\text { Perusahaan manufaktur yang terdaftar di Bursa Efek Indonesia } \\
\text { secara konsisten pada periode } 1 \text { Januari } 2013 \text { sampai dengan } \\
31 \text { Desember 2017. }\end{array}$ & 133 & 399 \\
$\begin{array}{l}\text { Perusahaan manufaktur yang tidak mempublikasikan laporan } \\
\text { keuangan dengan tahun buku yang berakhir pada 31 Desember. }\end{array}$ & (2) & (6) \\
$\begin{array}{l}\text { Perusahaan manufaktur yang tidak menerbitkan laporan keuangan } \\
\text { dalam mata uang Rupiah. }\end{array}$ & (27) \\
$\begin{array}{l}\text { Perusahaan manufaktur yang tidak secara konsisten menghasilkan } \\
\text { laba untuk periode buku tahun 2014 sampai dengan 2016. }\end{array}$ & (18) \\
$\begin{array}{l}\text { Perusahaan manufaktur yang membagikan dividen secara } \\
\text { konsisten untuk periode buku tahun 2015 sampai dengan 2017. }\end{array}$ & (58) \\
$\begin{array}{l}\text { Perusahaan manufaktur yang tidak memiliki data lengkap sesuai } \\
\text { kebutuhan penelitian ini. }\end{array}$ & $(2)$ & (174) \\
\hline $\begin{array}{l}\text { Jumlah data sebelum outlier } \\
\text { Jumlah data yang outlier } \\
\text { Jumlah data final setelah outlier }\end{array}$ & $\mathbf{3 8}$ \\
\hline
\end{tabular}

\section{Hasil Uji Kualitas Data}

a. Hasil Uji Normalitas Data

Uji normalitas bertujuan untuk mengetahui apakah data residual dalam model regresi berdistribusi normal atau tidak. Pengujian normalitas dapat dilakukan dengan uji Kolmogorov-Smirnov Test dengan nilai signifikansi 0,05. Hasil pengujian normalitas dapat dilihat pada tabel berikut: 
Tabel 2. Hasil Uji Normalitas Data Sebelum Outlier

\begin{tabular}{cc}
\hline & Unstandardized Residual \\
Asymp. Sig. $(2$-tailed $)$ & 0,000 \\
\hline $\mathrm{N}$ & 114 \\
\hline Sumber: Pengolahan data
\end{tabular}

Sumber: Pengolahan data

Berdasarkan tabel 2, nilai dari asymp. sig. (2-tailed) adalah 0,000 lebih kecil dari 0,05, hal ini menunjukkan bahwa data residual tidak berdistribusi normal. Oleh karena itu, dilakukan uji outlier untuk mengurangi data yang bersifat ekstrim. Setelah dilakukan uji outlier, terdapat 3 data yang harus dihilangkan sehingga jumlah data menjadi 111 data.

b. Hasil Uji Outlier

Uji outlier dilakukan apabila data yang diuji dengan menggunakan Kolmogorov-Smirnov Test menunjukkan hasil bahwa data tidak berdistribusi normal. Hasil dari pengujian normalitas data residual setelah dilakukan uji outlier dapat dilihat pada tabel berikut:

Tabel 3. Hasil Uji Normalitas Data Setelah Outlier

\begin{tabular}{cc}
\hline & Unstandardized Residual \\
\hline Asymp. Sig. (2 -tailed) & 0,071 \\
$\mathrm{~N}$ & 111 \\
\hline
\end{tabular}

Sumber: Pengolahan data

Berdasarkan tabel 3, setelah menghilangkan data yang outlier, data residual mempunyai nilai asymp.sig (2-tailed) sebesar 0,071 lebih besar dari 0,05 sehingga dapat disimpulkan bahwa data residual berdistribusi normal. Oleh karena itu, data yang digunakan adalah data setelah dilakukan uji outlier yaitu 111 data.

\section{Pengujian Hipotesis}

a. Analisis Koefisien Korelasi (R)

Uji koefisien korelasi (R) dilakukan untuk menguji kekuatan hubungan antara variabel independen dengan dependen. Hasil analisis koefisien korelasi adalah sebagai berikut:

Tabel 4. Hasil Analisis Koefisien Korelasi

\begin{tabular}{cc}
\hline Model & $\mathbf{R}$ \\
\hline 1 & 0,682 \\
\hline \multicolumn{2}{c}{ Sumber: Pengolahan data SPSS versi 23}
\end{tabular}

Berdasarkan analisis koefisien korelasi (R) pada tabel 4 menunjukkan bahwa nilai koefisien korelasi (R) adalah sebesar 0,682 lebih besar dari 0,5. Hal ini menunjukkan bahwa hubungan antara market price to book value ratio (MPBV), umur perusahaan (AGE), market capitalization (MARCAP), debt-equity ratio (DER), earnings per share 
(EPS), likuiditas (CR), dan tingkat pertumbuhan aset (GROWTH) terhadap kebijakan dividen (DPR) dalam model regresi adalah kuat.

b. Analisis Koefisien Determinasi (Adjusted $\mathrm{R}^{2}$ )

Uji koefisien determinasi (Adjusted $\mathrm{R}^{2}$ ) dilakukan untuk mengukur seberapa jauh kemampuan model dalam menerangkan variasi variabel dependen. Hasil analisis koefisien determinasi adalah sebagai berikut:

\section{Tabel 5. Hasil Analisis Koefisien Determinasi}

\begin{tabular}{cc}
\hline Model & Adjusted $\boldsymbol{R}$ Square \\
\hline 1 & 0,429 \\
\hline \multicolumn{2}{c}{ Sumber: Pengolahan data }
\end{tabular}

Analisis koefisien determinasi pada penelitian ini dapat dilihat pada tabel 5, nilai adjusted $\mathrm{R}^{2}$ sebesar 0,429 atau $42,9 \%$. Hal ini berarti besarnya persentase variasi dari variabel dependen yaitu kebijakan dividen (DPR) yang dapat dijelaskan oleh variasi variabel independen yaitu market price to book value ratio (MPBV), umur perusahaan (AGE), market capitalization (MARCAP), debt-equity ratio (DER), earnings per share (EPS), likuiditas (CR), dan pertumbuhan aset (GROWTH) adalah sebesar 42,9\% dan sisanya sebesar $57,1 \%$ dijelaskan oleh variasi dari variabel lain yang tidak termasuk dalam model dan dianggap tetap.

c. Hasil Uji Statistik F

Uji statistik F dilakukan untuk menunjukkan apakah semua variabel independen yang dimasukkan dalam model memiliki pengaruh secara bersama-sama terhadap variabel dependen. Uji statistik F juga bertujuan untuk mengetahui apakah model regresi layak dan tepat untuk pengambilan keputusan dalam penelitian ini atau tidak. Hasil uji statistik F adalah sebagai berikut:

Tabel 6. Hasil Uji Statistik F

\begin{tabular}{cc}
\hline Model & Sig. \\
\hline 1 & 0,000 \\
\hline \multicolumn{2}{c}{ Sumber: Pengolahan data }
\end{tabular}

Tabel 6 menunjukkan bahwa nilai signifikansi adalah 0,000 lebih kecil dari 0,05. Hal ini menunjukkan model regresi yang digunakan dalam penelitian ini adalah fit sehingga data layak digunakan dalam pengambilan keputusan.

d. Hasil Uji Statistik $\mathrm{t}$

Uji statistik $\mathrm{t}$ bertujuan untuk menunjukkan seberapa jauh pengaruh satu variabel independen secara individual dalam menerangkan variasi variabel dependen. Hasil uji statistik $\mathrm{t}$ adalah sebagai berikut: 
Tabel 7. Hasil Uji Statistik t

\begin{tabular}{|c|c|c|c|}
\hline Variabel & B & Sig. & Keterangan \\
\hline MPBV & 0,017000 & 0,000 & $\mathrm{Ha}_{1}$ dapat diterima \\
\hline AGE & 0,000000 & 0,934 & $\mathrm{Ha}_{2}$ tidak dapat diterima \\
\hline MARCAP & 0,000035 & 0,591 & $\mathrm{Ha}_{3}$ tidak dapat diterima \\
\hline DER & $-0,1910000$ & 0,000 & $\mathrm{Ha}_{4}$ dapat diterima \\
\hline EPS & 0,000038 & 0,027 & $\mathrm{Ha}_{5}$ dapat diterima \\
\hline CR & $-0,004000$ & 0,613 & $\mathrm{Ha}_{6}$ tidak dapat diterima \\
\hline GROWTH & $-0,340000$ & 0,013 & $\mathrm{Ha}_{7}$ dapat diterima \\
\hline
\end{tabular}

Sumber: Pengolahan data

Model persamaan regresi berganda pada penelitian ini diperoleh dari hasil pengolahan data statistik dari tabel 7 adalah sebagai berikut:

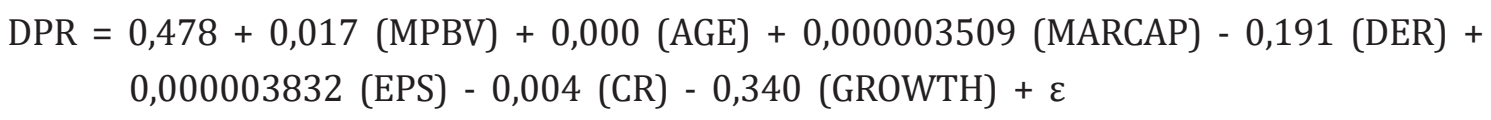

Berdasarkan hasil pada tabel 7 dan persamaan regresi berganda, dapat diuraikan variabel Market Price to Book Value (MPBV) memiliki nilai signifikansi 0,000 dengan nilai koefisien 0,017. Karena nilai signifikasi lebih kecil dari 0,05, hasil ini menunjukkan bahwa Hipotesis $1\left(\mathrm{Ha}_{1}\right)$ diterima, yaitu Market Price to Book Value berpengaruh terhadap kebijakan dividen. Nilai koefisiennya menunjukkan arah yang positif yang berarti semakin tinggi Market Price to Book Value, maka semakin besar perusahaan membayarkan dividennya kepada para investor. Adanya kesempatan investasi di masa yang akan datang tidak menutup kemungkinan dividen para pemegang saham akan dibayarkan oleh perusahaan.

Hasil pengujian menunjukkan bahwa variabel umur perusahaan (AGE) memiliki signifikansi 0,934 di atas 0,05, yang berarti Hipotesis $2\left(\mathrm{Ha}_{2}\right)$ tidak dapat diterima. Hasil tersebut menunjukkan bahwa umur perusahaan tidak berpengaruh terhadap kebijakan dividen. Keputusan mengenai perusahaan akan membagikan dividen atau tidak tidak tergantung pada lamanya perusahaan berdiri, tetapi tergantung pada kebijakan masingmasing perusahaan.

Hasil pengujian menunjukkan bahwa variabel market capitalization (MARCAP) memiliki signifikansi 0,591 di atas 0,05, yang berarti Hipotesis $3\left(\mathrm{Ha}_{3}\right)$ tidak dapat diterima. Hasil tersebut menunjukkan bahwa market capitalization tidak berpengaruh terhadap kebijakan dividen. Perusahaan yang tergolong besar memiliki akses dana ke pasar modal, sehingga hal ini tidak mempengaruhi keputusan perusahaan untuk membayarkan dividen kepada para pemagang saham atau tidak.

Hasil pengujian menunjukkan variabel Debt Equity Ratio (DER) memiliki nilai signifikansi 0,000 dengan nilai koefisien -0,191. Karena nilai signifikasi lebih kecil dari 0,05, hasil ini menunjukkan bahwa Hipotesis $4\left(\mathrm{Ha}_{4}\right)$ diterima, yaitu Debt Equity Ratio 
berpengaruh terhadap kebijakan dividen. Nilai koefisiennya menunjukkan arah yang negatif yang berarti semakin tinggi Debt Equity Ratio, maka semakin kecil perusahaan membayarkan dividennya kepada para investor. Perusahaan yang memiliki sumber pendaan yang lebih besar berasal dari utang, cenderung membayarkan dividen kepada pemegang saham lebih kecil.

Hasil pengujian menunjukkan variabel Earnings per Share (EPS) memiliki nilai signifikansi 0,027 dengan nilai koefisien 0,00003509. Karena nilai signifikasi lebih kecil dari 0,05, hasil ini menunjukkan bahwa Hipotesis $5\left(\mathrm{Ha}_{5}\right)$ diterima, yaitu Earnings per Share berpengaruh terhadap kebijakan dividen. Nilai koefisiennya menunjukkan arah yang positif yang berarti semakin tinggi Earnings per Share, maka semakin besar perusahaan membayarkan dividennya kepada para investor. Dividen merupakan bagian laba perusahaan yang didistribusikan kepada para pemegang saham, sehingga semakin besar laba yang dihasilkan oleh perusahaan semakin besar pula jumlah dividen yang dibagikan kepada para pemegang saham.

Hasil pengujian menunjukkan bahwa variabel likuiditas (CR) memiliki signifikansi 0,613 di atas 0,05, yang berarti Hipotesis $6\left(\mathrm{Ha}_{6}\right)$ tidak dapat diterima. Hasil tersebut menunjukkan bahwa likuiditas tidak berpengaruh terhadap kebijakan dividen. Keputusan mengenai perusahaan akan membagikan dividen atau tidak tidak tergantung pada rasio lancar perusahaan, tetapi tergantung pada kebijakan masing-masing perusahaan.

Hasil pengujian menunjukkan variabel pertumbuhan aset perusahaan (GROWTH) memiliki nilai signifikansi 0,013 dengan nilai koefisien -0,340. Karena nilai signifikasi lebih kecil dari 0,05, hasil ini menunjukkan bahwa Hipotesis $7\left(\mathrm{Ha}_{7}\right)$ diterima, yaitu pertumbuhan aset perusahaan berpengaruh terhadap kebijakan dividen. Nilai koefisiennya menunjukkan arah yang negatif yang berarti semakin tinggi pertumbuhan aset perusahaan, maka semakin besar perusahaan membayarkan dividennya kepada para investor. Perusahaan yang tingkat pertumbuhan asetnya besar tentunya memiliki banyak tingkat investasi aset yang harus segera dibiayai untuk tujuan ekspansi, sehingga semakin sedikit dividen yang dibayarkan kepada para pemegang saham.

\section{SIMPULAN}

Berdasarkan hasil pengujian statistik yang dilakukan terhadap 37 perusahaan manufaktur yang menjadi sampel penelitian, maka diperoleh kesimpulan sebagai berikut: 1) Market price to book value ratio memiliki pengaruh terhadap kebijakan dividen; 2) Umur perusahaan tidak memiliki pengaruh terhadap kebijakan dividen; 3) Market capitalization tidak memiliki pengaruh terhadap kebijakan dividen; 4) Debt equity ratio tidak memiliki pengaruh terhadap kebijakan dividen; 5) Earnings per share memiliki pengaruh terhadap kebijakan dividen; 6) Likuiditas tidak memiliki pengaruh terhadap kebijakan dividen; dan 7) Tingkat pertumbuhan aset memiliki pengaruh terhadap kebijakan dividen.

Implikasi dari hasil penelitian ini adalah investor perlu mendapatkan informasi dan menganalisisnya sebelum melakukan keputusan investasi, salah satunya adalah dengan mempertimbangkan rasio-rasio keuangan, terutama MPBV, rasio earnings per share dan 
tingkat pertumbuhan aset yang merupakan penentu di dalam kebijakan dividen perusahaan. Bagi pihak manajemen perusahaan sebaiknya memberikan informasi yang lengkap dan akurat tentang kondisi perusahaan sebagai bahan pertimbangan bagi investor yang akan menginvestasi dananya.

\section{PUSTAKA ACUAN}

Alphonse, P., \& Tran, Q. T. (2014). A Two-Step Approach to Investigate Dividend Policy: Evidence from Vietnamese Stock Market. International Journal of Economics and Finance. https://doi.org/10.5539/ijef.v6n3p16

Damayanti, Y. I., \& Martiningtiyas, C. (2014). Faktor-Faktor yang Mempengaruhi Kebiajakan Pembayaran Dividen. E- Journal Manajemen Fakultas Ekonomi, 1(2), 70-83.

Darminto. (2008). Pengaruh profitabilitas, likuiditas, struktur modal, dan kepemilikan saham terhadap kebijakan dividen. Jurnal Ilmu-Ilmu Sosial.

Devi, N., \& Erawati, N. (2014). Pengaruh Kepemilikan Manajerial, Leverage, Dan Ukuran Perusahaan Pada Kebijakan Dividen Perusahaan Manufaktur. E-Jurnal Akuntansi, 9(3), 709-716.

Kieso, Weygandt, \& warfield. (2017). Akuntansi Keuangan Menengah Intermediate Accounting. Salemba Empat.

Kuzucu, N. (2015). Determinants of Dividend Policy: A Panel Data Analysis for Turkish Listed Firms. International Journal of Business and Management. https://doi.org/10.5539/ ijbm.v10n11p149

Maladjian, C., \& Khoury, R. El. (2014). Determinants of the Dividend Policy: An Empirical Study on the Lebanese Listed Banks. International Journal of Economics and Finance.

Marietta, U., \& Sampurno, D. (2013). Analisis Pengaruh Cash Ratio, Return On Assets, Growth, Firm Size, Debt to Equity Ratio Terhadap Dividend Payout Ratio : (Studi Pada Perusahaan Manufaktur Yang Terdaftar di Bursa Efek Indonesia Tahun 2008-2011). Diponegoro Journal of Management, 2(3), 1-11. Retrieved from http://ejournal-s1. undip.ac.id/index.php/dbr

Pasaribu, R. B. F., Kowanda, D., \& Nawawi, K. (2014). Determinan Dividend Payout Ratio pada Emiten LQ-45 di Bursa Efek Indonesia. Jurnal Ekonomi \& Bisnis.

Ressy, A. E., \& Chariri, A. (2013). Pengaruh Kinerja Keuangan terhadap Kebijakan Dividen di Bursa Efek Indonesia. Diponegoro Journal of Accounting, 2(3), 13-22.

Ritha, H., \& Koestiyanto, Ek. (2013). Faktor-Faktor yang Mempengaruhi Dividend Payout Ratio (DPR). E-Journal Manajemen Dan Bisnis.

Singhania, M., \& Gupta, A. (2012). Determinants of Corporate Dividend Policy: A Tobit Model Approach. Vision: The Journal of Business Perspective. https://doi. org/10.1177/0972262912460152

Sunarya, D. H. (2013). Pengaruh Kebijakan Utang, Profitabilitas Dan Likuiditas Terhadap Kebijakan Dividen Dengan Size Sebagai Variabel Moderasi Pada Sektor Manufaktur. Jurnal Ilmiah Mahasiswa Universitas Surabaya. 
Takhtaei, N. (2014). Relationship between Firm Age and Financial Leverage with Dividend Policy. Asian Journal of Finance \& Accounting, 6(2), 53. https://doi.org/10.5296/ajfa. v6i2.5910

Tariq, A. (2015). the Joint-Determinants of Leverage and Dividend Policy: a Balanced Panel Study of Non Financial Firms of India and Pakistan. European Scientific Journal.

Thanatawee, Y. (2011). Life-Cycle Theory and Free Cash Flow Hypothesis: Evidence from Dividend Policy in Thailand. International Journal of Financial Research, 2(2), 52-60. https://doi.org/10.5430/ijfr.v2n2p52

Zameer, H., Rasool, S., Iqbal, S., \& Arshad, U. (2013). Determinants of dividend policy: A case of banking sector in pakistan. Middle East Journal of Scientific Research. https:// doi.org/10.5829/idosi.mejsr.2013.18.3.12200 